have to deal with plant material in the identification of their specimens. Those working with timber should obtain considerable help in the identification of hardwoods, based on the study of no less than eighteen hundred species. The details of the structure of leaves and young stems should be of value to those who are examining material imported for use as drugs, flavourings, or other purposes, while the systematic botanist and forester will be supplied with a wealth of information useful in the identification of trees and herbs. The authors have spent ten years in the compilation of the material in this monumental work, and it is not likely to be superseded for very many years.

${ }^{1}$ Sporne, New Phytologist, 48, 259 (1949).

\section{BACTERIAL DISEASES OF CROP PLANTS}

Manual of Bacterial Plant Diseases

By Dr. W. J. Dowson. Pp. viii $+183+32$ plates. (London: Adam and Charles Black, Ltd., 1949.) $16 s$. net.

$7 \mathrm{HE}$ honest student of plant pathology will readily admit that there are considerable gaps in his knowledge of bacterial plant pathogens. This is at present no reflexion on his professional zeal, for, since the classical work of Erwin F. Smith, there have been few available collected works on the subject. Methods have, moreover, advanced apace, and knowledge of diseases has increased very greatly. Dr. W. J. Dowson, having experienced this lack of accumulated literature while lecturing, very rightly decided to remove the incubus. $\mathrm{He}$ is well qualified to do this, having been, for many years, the specialist to whom almost all the plant pathologists in Great Britain have referred problems on bacterial disease. The result is a thoroughly helpful and authoritative volume.

Perhaps the number of bacterial maladies may seem large to the crop producer ; but it should be remembered that Dr. Dowson has drawn a very comprehensive list. Many diseases are described which bring considerable loss in one country but cause little damage in others. All the known bacterial maladies occurring in Britain, and most of those important in the British Dominions, Colonies and Dependencies are included; but a few diseases, recorded so far only from the United States of America, are either omitted or but briefly mentioned. The method of bacterial classification is the author's own modification, but most generic names are already familiar in Great Britain.

A section on methods assumes a knowledge of routine basic methods; but it then becomes a very useful and modern exposition, with all the simple practical features usually developed only by the enthusiast. The platinum needle has, for example, given place to a thin glass rod, with advantage when streaking out plates. Forty excellent half-tone figures illustrate methods, bacteria and disease symptoms, while eighteen world-distribution maps prepared by the Commonwealth Bureau of Mycology make useful contributions in this new setting. Methods for control draw largely on the preventive implications of eultural hygiene; but practical control is probably the least satisfactory section of the subject. This is no criticism of the author or of the book, but rather the cri de cour of an advisory officer at his relative impotence in the face of increasing incidence of bacterial soft rots on agricultural crops. Hygiene is difficult under those conditions, and treatment of dormant organs impracticable.

Plant pathology is, however, only now celebrating the centenary of its inception, and merely its comingof-age as a vigorous science. Dr. Dowson's book should provide the basis for a considerable impetus to the study of bacterial plant diseases. JoHN GraINGER

\section{INTENSIVE CULTIVATION OF VEGETABLES}

\section{Intensive Salad Production}

Including some Vegetables. By C. P. Quarrell. (Agricultural and Horticultural Series.) Fourth revised edition. Pp. xviii $+277+16$ plates. (London : Crosby Lockwood and Son, Ltd., 1949.) 15s. net.

70 the commercial grower and to the student a 1 new edition of C. P. Quarrell's book is a matter of some importance. This is something more than a mere revision of the earlier editions; it is almost a new book. There could not be a better illustration of the rapidity with which horticultural knowledge has grown since the Second World War than the changes which four years have necessitated in the text. Up to 1945 (the date of the third edition) intensive salad production meant almost exclusively the Dutch-light systems pioneered in Great Britain by Mr. F. A. Secrett. Since that date a multitude of other types of protective devices have appearedcloches, frames and structures of different kinds, sizes and shapes in bewildering variety - and many of these have proved themselves of economic value to the commercial grower. Their adoption has meant new cropping systems and the introduction of a greater diversity of crops into the rotations, and new varieties of plants have been produced to meet. the changed needs.

The introduction of entirely new synthetic insecti cides and fungicides, the astonishingly rapid growth in the use of overhead irrigation and the development. by the British Electrical and Allied Industries Research Association of low-voltage electrical methods of soil warming have all made this now edition imperative. There is scarcely any branch of horticultural production to which the results of war-time and post-war research have been more usefully applied than to protected cultivation. Quarrell's book has become the standard reference for the grower and the chief source of study in this field for the student, and he has earned a debt of gratitude by preparing this careful revision. The photographs and diagrams have been most carefully chosen to illustrate the text; but the addition of a few diagrams to illustrate the section on soil warming by electricity would have been of great value.

For ease of reference it would be en improvement to divide the section on diseases into two chapters and to print the name of the host plant in larger type than that of the parasite. Though cultivation of salad crops in glasshouses is dealt with, no mention is made of the new insecticidal smokes and continuous-phase aerosols which show so much promise in labour saving. Not the least valuable part of the volume as a reference book is the final section of tables, miscellaneous data and selected references to the literature, which bring together much that is so often difficult to find. $\quad$ R. H. Stoughton 